\title{
Ben C. Blackwell, John K. Goodrich, and Jason Maston, Eds. Reading Mark in Context: Jesus and Second Temple Judaism
}

(Grand Rapids: Zondervan, 2018), 286 pp.

\author{
NICHOLAS A. ELDER \\ nick.elder@marquette.edu \\ Marquette University, Milwaukee, WI 53233
}

Reading Mark in Context is a collection of thirty essays that sequentially interprets passages in Mark with specific reference to relevant Second Temple Jewish texts. The volume includes a foreword by N. T. Wright that notes its dual purpose, which is to (1) introduce the reader to Jewish texts from the Second Temple period and (2) provide a "running commentary" on Mark in light of those texts (pp. 1415). Preceding the collection's thirty essays is an introduction from the editors that serves several functions. First, they briefly review historical Jesus scholarship in order to highlight the importance of non-canonical Second Temple Jewish texts for understanding Jesus as he is presented in the gospels. Second, they identify the kind of readers that the volume is primarily intended for, namely beginning to intermediate students who are evangelical. Third, it offers an introduction to the Second Temple period with reference to major events and writings.

As a whole, the collection of essays is well-balanced. Each contribution is approximately seven pages long and is evenly divided between an introduction to a Second Temple Jewish text and an interpretation of Mark in light of that text. A broad swath of Second Temple literature is represented, including the Letter of Aristeas, the Psalms of Solomon, 4 Ezra, the Book of Jubilees, 1 Maccabees, 2 Maccabees, and various texts from Qumran, Philo, Josephus, Rabbinic literature, and the Enochic corpus. As is the case with any collection, the contributions vary in strength. In what follows I will highlight two particularly notable essays before commenting on the collection as a whole.

In her essay "The Letter of Aristeas and Mark 7:1-23: Developing Ideas of Defilement," Sarah Whittle interprets Mark 7, in which Jesus discusses moral and ritual impurity, in light of the Letter of Aristeas. Whittle introduces Aristeas before turning to the interpretation of dietary laws from Leviticus 11 and Deuteronomy 
14. She shows that for Aristeas "moral values [are] embodied in the dietary rules" (p. 111). For example, the author explains that mice are not suitable for consumption because they are destructive and damaging. In general, Aristeas promotes ritual practices by offering moral rationales for them. While Mark takes the connection between moral and ritual purity in a different direction than Aristeas, namely by stating that moral purity is prioritized over ritual observance, the latter is an interpretive comparandum for the former. Both Mark and Aristeas find a connection between moral and ritual purity. This essay is strong in its introduction to and interpretation of Aristeas on its own terms and also in demonstrating its value for illuminating the Gospel.

Sigurd Grindheim, in "Sirach and Mark 8:27-9:13: Elijah and Eschaton," similarly sets two traditions in conversation with one another without privileging one over the other. In Grindheim's case the traditions are concerned with Elijah. Having addressed introductory issues related to Sirach, Grindheim offers Sirach 48:1-11 as a text that reveals Second Temple Jewish expectations of Elijah's eschatological role, largely based on Malachi 4:6. Grindheim is careful to note that in Sirach, as in other Second Temple traditions, "the coming of Elijah did not have anything in particular to do with the Messiah, but it had everything to do with what God was going to do at the end of time" (p. 135). Sirach has a high view of Elijah and his eschatological function. Drawing on the tradition, Grindheim says Elijah's presence at the Transfiguration in Mark 9 tells the reader something about the Gospel's own eschatological expectations. Moreover, given that Elijah has nothing to do with a messianic figure in Sirach but is eschatologically significant in his own right, the Markan interpreter is better able to perceive the Gospel's "muting" of Elijah at the transfiguration (p. 133). Mark has "reduced Elijah to a silent extra" and funneled both messianic and eschatological expectations into Jesus.

Both of the essays reviewed here situate the Gospel within its Second Temple Jewish context. The strongest contributions to the collection accurately represent the Second Temple Jewish text, note that text's relevant distinctive features, and then juxtapose these with a passage from Mark without making the Gospel the standard by which the Second Temple Jewish text is judged.

Some essays in the volume, however, appear simply to be using a Jewish text as a negative foil to Mark. Their contrasts appear designed to reflect what the authors view as superior (read: Christian) value systems. For example, Jeffrey W. Aernie writes, "Unlike the rigid corporate boundaries developed in the Rule of the Community, the defining boundaries around the community of Jesus's followers are extremely porous" (p. 148). In the conclusion to his essay comparing Mark 10:32-52 with the Rule of the Congregation, John K. Goodrich writes, "The Rule rewards knowledge, skills, and piety, stressing the priority and preeminence of those with greater status, beginning with the priest and Messiah. Mark's Gospel, on the other hand, promotes servant-style leadership rooted in the Messiah's own self-giving" (p. 172). While not all the essays in this volume, nor even the majority of them, are characterized by this sort of rhetoric, it is common enough in several essays to be notable. This leads to another critique of the collection. The contributors are, for the most part, New Testament scholars with secondary interests in 
Second Temple Judaism. For nearly all of them, Mark is the ultimate text of inquiry; the Jewish texts are valuable primarily as aids to the interpretation of Mark. While this is not necessarily a problem in and of itself, it might have been productive also to enlist scholars who specialize in Second Temple Judaism and then to have them study the Gospel. This would "flip the script", so to speak.

Despite these two critiques, the collection as a whole accomplishes its intent well. It serves as an excellent introduction to a wide variety of early Jewish texts and traditions and productively situates Mark within its Second Temple Jewish context. The text would serve very well in an upper-division New Testament course at an evangelical university or seminary. I envision a syllabus in which essays from the collection are paired with primary source readings from the Second Temple Jewish texts and Markan pericopae that they address. For this reason alone, the text should be on the bookshelf of New Testament educators teaching in evangelical contexts. 